\title{
PERENCANAAN ARSITEKTUR SISTEM INFORMASI REKAM MEDIS DAN MONITORING GIZI BURUK DENGAN MENGGUNAKAN TOGAF ADM
}

\author{
(Studi Kasus : Dinas Kesehatan Propinsi Jawa Barat)
}

\author{
Ova Nurisma Putra \\ Lembaga Penelitian dan Pengabdian Masyarakat (LPPM) STMIK JABAR Bandung \\ STMIK JABAR
}

Jl. Soekarno-Hatta No. 777 Tlp. (022) 7335108 Bandung 40293

ova.np@stmikjabar.ac.id

\begin{abstract}
Abstrak
Dinas Kesehatan Propinsi Jawa Barat masih mengalami kesulitan dalam pengelolaan informasi yang baik, terutama pada proses rekam medis, pencatatan dan pelaporan gizi buruk masih dilakukan secara bertingkat mulai pengumpulan data dari bidan desa, puskesmas, Dinas Kesehatan Kabupaten/Kota kemudian Dinas Kesehatan Propinsi dan diteruskan ke pusat. Sehingga perlu diupayakan pengelolaan informasi melalui sistem pelayanan dengan memanfaatkan teknologi informasi berbasis Cloud Computing.

Penelitian ini membahas mengenai tiga iterasi dari seluruh fase yang ada di The Open Group Architecture Framework (TOGAF) Architecture Development Method (ADM), yaitu iterasi ke satu pada Architecture Capability Iteration, iterasi ke dua pada Architecture Development Iteration dan iterasi ke tiga pada Transition Planning Iteration. Dan Monitoring dan Evaluasi (M\&E) merupakan dua kegiatan terpadu dalam rangka pengendalian suatu program.

Hasil dari penelitian ini adalah perencanaan arsitektur sistem informasi rekam medis dan monitoring gizi buruk berbasis Cloud Computing dengan nama M2Rec (Medical Record and Monitoring) yang berupa rekomendasi integrasi dan pengembangan antara sistem informasi berjalan saat ini dengan arsitektur sistem informasi yang diusulkan.

Kata Kunci : Arsitektur Bisnis, Arsitektur Data, Arsitektur Aplikasi, Arsitektur Teknologi, TOGAF ADM, Medical Record and Monitoring, Cloud Computing.
\end{abstract}

\begin{abstract}
Provincial Health Office of West Java are still experiencing difficulties in the management of good information, especially in the medical record, recording and reporting of malnutrition is still done in stages begin collecting data from midwives, community health centers, the District Health Office I City then PHO and forwarded to the center. So that needs to be pursued through the information management system by utilizing information technology services based on Cloud Computing.

This study discusses the three iterations of all phases in The Open Group Architecture Framework (TOGAF) Architecture Development Method (ADM), the iteration of the Architecture Capability Iteration, iterations to two on Architecture Development Iteration and iteration to three on Transition Planning iteration. And Monitoring and Evaluation $(M \& E)$ is an integrated two activities to prevent and control program.

Results from this study is the architectural planning of medical record information system and monitoring of malnutrition based Cloud Computing with M2Rec name (Medical Record and Monitoring) in the form of recommendations and the development of integration between information systems currently running with the proposed information system architecture.
\end{abstract}

Keywords: Business Architecture, Data Architecture, Application Architecture, Architectural Technology, TOGAF ADM, Medical Record and Monitoring, Cloud Computing 


\section{Pendahuluan}

Berdasarkan data kesehatan Dinas Kesehatan Provinsi Jawa Barat melalui Badan Pusat Statistik Jawa Barat bahwa pada tahun 2014, jumlah bayi lahir hidup adalah 950.541 dengan 20.465 bayi lahir dengan berat badan rendah $(2,15 \%)$. Sedangkan jumlah balita adalah 4.435.523 dan ditemukan 3.126 balita gizi buruk $(0,07 \%)$. Maka sangat diperlukan adanya perencanaan arsitektur sistem informasi rekam medis dan monitoring gizi buruk dalam upaya memantau tingkat kesehatan di desa, kota dan kabupaten dengan melihat beberapa indikator yang dapat mempengaruhi gizi buruk seperti dari jumlah penduduk, jumlah balita, jumlah tenaga medis, posyandu, puskesmas dan balai pengobatan.

Berdasarkan hal tersebut di atas, maka perencanaan arsitektur sistem informasi rekam medis dan monitoring gizi buruk disesuaikan pada kebutuhan pengguna dan proses bisnis Dinas Kesehatan Propinsi Jawa Barat, sehingga menghasilkan perencanaan arsitektur sistem informasi yang dapat meningkatkan kinerja dan pelayanan yang optimal.

Proses Bisnis pada sistem informasi saat ini di Dinas Propinsi Jawa Barat sebagian masih belum memiliki aplikasi yang berjalan secara komputerisasi, hanya menggunakan cara manual dari tahapan pendaftaran di tingkat bidan desa, pencatatan di puskesmas oleh bidan koordinator yang berkoordinasi dengan pengelola program gizi dimana Sistem Pencatatan dan Pelaporan Terpadu Puskesmas (SP2TP) dan Sistem PWS-GIZI di tingkat puskesmas dan Sistem Kewaspadaan Pangan Gizi (SKPG) kabupaten kemudian baru dilaporkan secara periodik setiap bulannya ke tingkat propinsi. Sistem ini memiliki kelemahan pada lamanya pelaporan yang dilakukan sehingga mengakibatkan pelaporan lambat di update secara periodik. Oleh karena itu akan dikembangkan menjadi sistem yang terintegrasi berbasis web-GIS dengan model arsitektur Cloud Computing dan menggunakan pendekatan TOGAF ADM. Semua data terekam secara terintegrasi/terpusat dari data pelayanan kesehatan, rekam medis, petugas medis, dokter, bidan, tempat berobat: posyandu, polindes, balai pengobatan, puskesmas ditiap wilayah pemeriksaan di propinsi Jawa Barat.

Perencanaan sistem ini bersifat mobile dapat diakses dalam waktu 24 jam, melalui smartphone, laptop/komputer yang terhubung ke internet sehingga informasi dapat dilihat dan dipantau kapan pun dan dimana saja. Perencanaan arsitektur sistem informasi ini dibuat berbasis IT dengan nama mobile M2Rec (Medical Record and Monitoring). Dengan menggunakan metodologi dan framework dalam penelitian ini menggunakan The Open Group Architecture Framework (TOGAF) Architecture Development Method (ADM).

\section{LANDASAN TEORI}

Enterprise Archiecture (EA) dapat diartikan sebagai cetak biru pemetaan hubungan antar komponen dan semua orang yang bekerja di dalam perusahaan secara konsisten untuk meningkatkan kerja sama/kolaborasi, serta koordinasi diantaranya (Ward dan Peppard, 2002). Enterprise bisa juga dikatakan sebuah perusahaan atau organisasi yang mempunyai struktur organisasi yang jelas dan mempunyai proses bisnis yang dikelola untuk menghasilkan produk atau menghasilkan layanan (Kurniawan, 2015). Enterprise Architecture adalah penjelasan eksplisit dan dokumentasi saat ini mengenai hubungan antara manajemen, proses bisnis dan Teknologi Informasi. Ini menggambarkan "arsitektur saat ini" dan "arsitektur target" untuk memasukkan aturan, standar dan siklus hidup sistem informasi untuk mengoptimalkan dan memelihara lingkungan organisasi yang ingin menciptakan dan memelihara dengan mengelola portofolio IT (Handley, 2008). Arsitektur enterprise merupakan istilah yang digunakan untuk logika pengorganisasian untuk seluruh organisasi, seringkali menentukan bagaimana teknologi informasi akan mendukung proses bisnis organisasi tersebut (Pearlson, Keri, Saunder dan Carol, 2010).

Dari definisi di atas dapat diambil kesimpulan bahwa arsitektur enterprise adalah penjelasan dan dokumen yang jelas dari keadaan organisasi mengenai proses bisnis, teknologi informasi dan hubungan antar sumberdaya yang terlibat yang menggambarkan arsitektur saat ini dan arsitektur yang akan datang meskipun dipisahkan oleh wilayah.

Dalam perencanaan arsitektur sistem informasi dapat menggunakan metodologi dan framework yang telah banyak tersedia, diantaranya menggunakan TOGAF ADM (Kosidin, 2015).

Ada beberapa definisi TOGAF diantaranya:

1. TOGAF adalah kerangka kerja yang terperinci dan seperangkat alat dalam pengembangan sebuah EA yang digunakan untuk mendesain, 
membangun dan mengevaluasi. (The Open Group, 2011)

2. TOGAF merupakan standar industri untuk metode pengembangan arsitektur dan sumber daya dasar yang dapat digunakan secara bebas oleh organisasi yang ingin mengembangkan arsitektur enterprise untuk digunakan dalam organisasi. (The Open Group dan OMG, 2003)

Dari definisi di atas dapat diambil kesimpulan bahwa TOGAF merupakan kerangka kerja yang terperinci dan bersifat open source yang bisa digunakan oleh setiap organisasi dalam rangka membangun suatu EA yang sesuai dengan kebutuhan organisasi. Kelebihan dari TOGAF adalah memiliki sifat yang fleksibel dan open source.

\section{A. Architecture Development Method}

ADM merupakan bagian utama dari TOGAF yang memberikan gambaran rinci bagaimana menentukan sebuah enterprise architecture secara spesifik berdasarkan kebutuhan bisnisnya. Melalui beberapa tahapan dan merupakan metodologi yang menjelaskan secara rinci bagaimana membangun, mengelola, dan mengimplementasikan suatu arsitektur enterprise dan sistem informasi yang sesuai dengan kebutuhan bisnis organisasi. Gambar 1 menunjukkan tahapan proses arsitektur dalam TOGAF ADM.

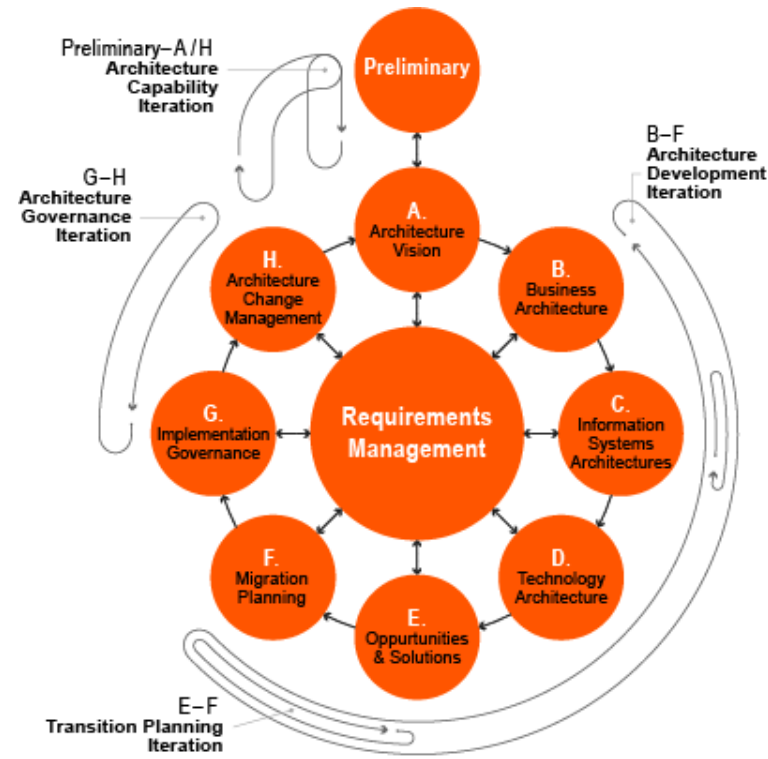

Gambar 1. Iterasi TOGAF ADM

(The Open Group, 2011: 182)
Penjelasan tahap-tahap proses arsitektur dalam TOGAF ADM:

1. Preliminary Phase

Merupakan fase persiapan yang bertujuan untuk mengkonfirmasi komitmen dari stakeholder, penentuan framework dan metodologi detil yang akan digunakan pada pengembangan EA. Dengan melakukan kegiatan persiapan dan inisiasi yang diperlukan untuk memenuhi arahan bisnis arsitektur enterprise baru, termasuk definisi kerangka kerja arsitektur organisasi secara spesifik, alat bantu dan definisi prinsip..

2. Tahap A : Visi Arsitektur (Architecture Vision)

Membuat keseragaman pandangan mengenai pentingnya arsitektur enterprise untuk mencapai tujuan organisasi yang dirumuskan dalam bentuk strategi serta menentukan ruang lingkup arsitektur yang akan dikembangkan.

3. Tahap B : Arsitektur Bisnis (Business Architecture)

Mendefinisikan kondisi awal arsitektur bisnis, menentukan model bisnis atau aktivitas bisnis yang diinginkan berdasarkan sekenario bisnis. Pemodelan bisnis dilakukan dengan mengidentifikasi area bisnis utama dan penunjang dengan menggunakan model rantai nilai (value chain).

4. Tahap C : Arsitektur Sistem Informasi (Information Sistem Architecture)

Arsitektur sistem informasi fokus pada kebutuhan data dan aplikasi yang direncanakan, dalam tahap ini terbagi menjadi dua arsitektur yaitu arsitektur data dan aplikasi.

5. Tahap D : Arsitektur Teknologi (Technology Architecture)

Membangun arsitektur teknologi yang diinginkan, dari mulai penentuan jenis teknologi yang diperlukan, yang meliputi jaringan, server, database, software dan hardware, dan mempertimbangkan alternatif-alternatif yang diperlukan dalam pemilihan teknologi.

6. Tahap E : Peluang dan Solusi (Oportunities and Solutions)

Tahapan ini fokus pada analisis manfaat yang diraih dari Arsitektur Enterprise (Bisnis, Data, Aplikasi, Teknologi) agar menjadi dasar 
bagi stakeholder untuk memilih dan menentukan arsitektur yang diimplementasikan.

7. Tahap F : Perencanaan Migrasi (Migration Planning)

Tahap ini berisi perencanaan migrasi antara sistem informasi yang telah ada dengan sistem informasi yang baru dengan menganalisis biaya, manfaat, dan resiko.

8. Tahap G : Implementasi Pengelolaan Arsitektur (Implementasi Governance)

Memastikan dan merekomendasikan pelaksanaan proyek sesuai dengan EA meliputi tata kelola organisasi, tata kelola sistem informasi, dan tata kelola arsitektur teknologi.

9. Tahap H : Arsitektur Manajemen Perubahan (Architecture Change Management)

Pemantauan dalam proses perubahan manajemen untuk memastikan bahwa EA merespon kebutuhan organisasi dan memaksimalkan nilai arsitektur untuk bisnis.

Dalam TOGAF ADM terdapat siklus iterasiiterasi yang bisa digunakan untuk membuat EA lebih fokus terhadap kebutuhan yang disesuai dengan organisasi. Iterasi yang terdapat pada TOGAF ADM terbagi menjadi:

1. Iterasi yang ke satu adalah Iterasi Kemampuan Arsitektur, merupakan kegiatan awal dari arsitektur yang berupa pendekatan arsitektur, prinsip, ruang lingkup, visi dan tata kelola.

2. Iterasi yang ke dua adalah Iterasi Membangun Arsitektur untuk membuat arsitektur dan mengintegrasikan antara fase arsitektur bisnis, arsitektur sistem informasi dan fase arsitektur teknologi. Pada iterasi ini semua arsitektur dianggap sebagai bagian dari keseluruhan fase pembangunan arsitektur.

3. Iterasi yang ke tiga adalah Iterasi Perencanaan Transisi, merupakan iterasi yang berupa peta jalan / road map bagi organisasi dalam penerapan arsitektur yang telah dibuat.

4. Iterasi yang ke empat adalah Iterasi Arsitektur Governance, merupakan iterasi yang mendukung sasaran perubahan arsitektur yang didefinisikan.

Dari iterasi-iterasi yang ada tersebut di atas dapat digunakan sebagai panduan dalam perencanaan dan pengembangan suatu arsitektur sistem informasi yang disesuaikan dengan tujuan dari pembuatan arsitektur sistem informasi tersebut.

\section{Metode Penelitian}

Perencanaan Sistem Informasi Rekam Medis dan Monitoring Gizi Buruk di Dinas Kesehatan Propinsi Jawa Barat dibuat dengan menggunakan pendekatan framework TOGAF ADM untuk membantu mengatasi permasalahan dalam proses bisnisnya yaitu pada proses rekam medis dan pelaporan setiap periodiknya yang dilakukan secara berjenjang dan mengakibatkan laporan terlambat untuk di update. Dengan dikembangkannya arsitektur sistem ini akan memberikan skema berupa blue print sistem informasi rekam medis dan monitoring gizi buruk secara terintegrasi melalui pemanfaatan pelayanan servis cloud computing dengan EA berbasis TOGAF ADM pada pengembangan arsitektur teknologinya.

Penelitian ini membahas tiga iterasi dari seluruh fase yang ada di TOGAF ADM, yaitu iterasi ke satu pada Architecture Capability Iteration, iterasi ke dua pada Architecture Development Iteration dan iterasi ke tiga pada Transition Planning Iteration. Dan Monitoring dan Evaluasi (M\&E) merupakan dua kegiatan terpadu dalam rangka pengendalian suatu program. Metode penelitian dapat dilihat pada Gambar 2, dengan penjelasannya sebagai berikut:

\section{Iterasi 1 : Architecture Capability Iteration}

Merupakan Iterasi Kemampuan Arsitektur untuk melakukan kegiatan awal dari arsitektur yang berupa pendekatan arsitektur, prinsip, ruang lingkup, visi dan tata kelola. Iterasi ini dilakukan pada tahap Preliminary dan tahap A.

\section{Preliminary (Tahap Awal)}

Identifikasi awal dengan melakukan studi literatur terhadap data dan referensi yang sesuai dengan penelitian berupa jurnal, buku dan informasi dari hasil browsing dan lain-lain berkaitan dengan topik yang dibahas. Hal ini dilakukan untuk dijadikan bahan sebagai landasan teori dalam penelitian ini. Tahapan ini melakukan identifikasi dan inisialisasi semua yang terkait dengan penelitian dengan cara observasi langsung ke tempat penelitian dan studi dokumen yang terkait dengan perencanaan arsitektur sistem informasi monitoring gizi buruk pada Dinas Kesehatan Propinsi Jawa Barat. Langkah-langkah yang dilakukan dalam tahapan ini meliputi:
Ova Nurisma Putra

Jurnal Ilmiah Teknologi Informasi Terapan Volume III, No 2, 15 April 2017 
a. Pengumpulan data-data yang terkait profil, visi misi, tujuan, struktur organisasi, tugas pokok dan fungsi organisasi Dinas Kesehatan Propinsi Jawa Barat.

b. Melakukan analisis dan identifikasi proses bisnis Dinas Kesehatan Propinsi Jawa Barat dalam upaya memonitoring dan evaluasi gizi buruk pada seksi kesehatan dan gizi.

c. Melakukan analisis dan identifikasi sistem dan teknologi informasi yang sedang berjalan saat ini oleh Dinas Kesehatan Propinsi Jawa Barat dalam menangani dan monitoring gizi buruk.

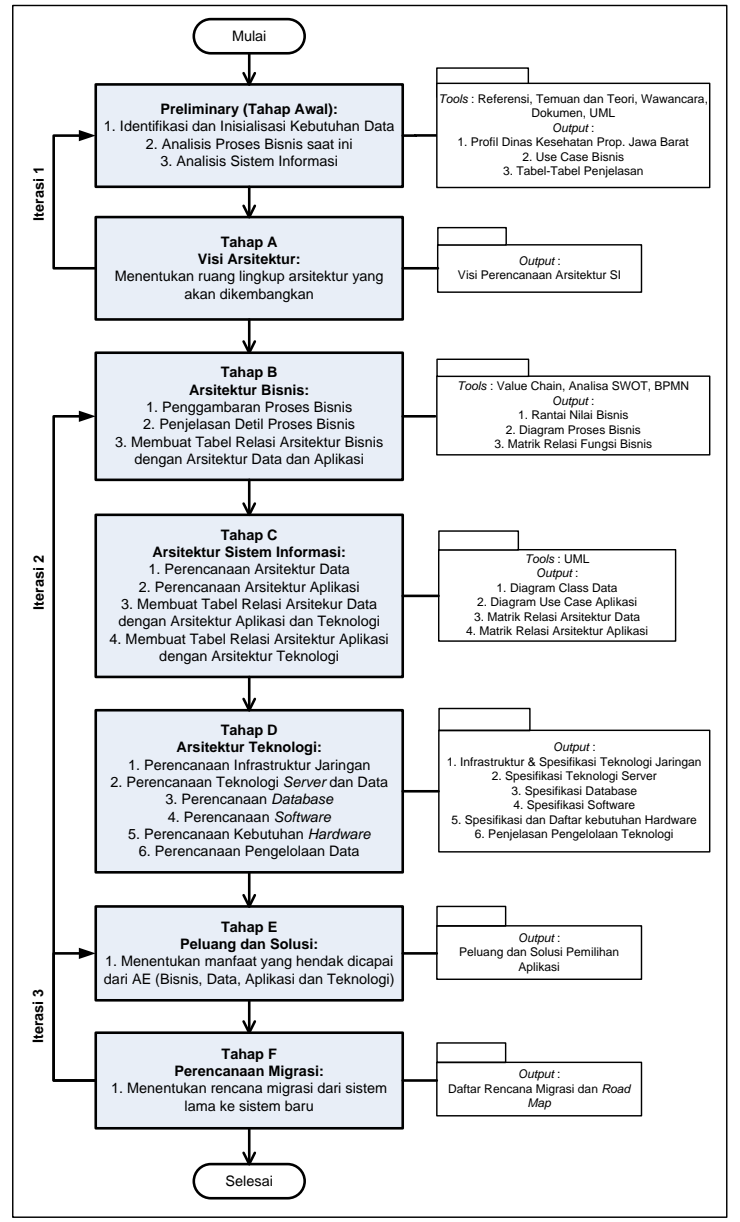

Gambar 2. Metode Penelitian

\section{Tahap A: Menentukan Visi Perencanaan Arsitektur}

Membahas mengenai visi dan hasil yang diinginkan dari pada hasil perencanaan arsitektur sistem informasi monitoring gizi buruk.

\section{Iterasi 2 : Architecture Development Iteration}

Iterasi Membangun Arsitektur untuk membuat arsitektur dan mengintegrasikan antara fase arsitektur bisnis, arsitektur sistem informasi dan fase arsitektur teknologi. Pada iterasi ini semua arsitektur dianggap sebagai bagian dari keseluruhan fase pembangunan arsitektur termasuk adanya deskripsi peluang dan solusi, serta kebutuhan untuk perencanaan transisi pada tahap membangun sistem. Tahapan-tahapan ini meliputi:

\section{Tahap B: Perencanaan Arsitektur Bisnis}

Melakukan analisis dan identifikasi terhadap proses bisnis pelayanan kesehatan dan gizi di Dinas Kesehatan dengan langkah sebagai berikut:

a. Melakukan analisis dan identifikasi terhadap proses bisnis Dinas Kesehatan Propinsi Jawa Barat dengan rantai nilai Porter dan analisis SWOT (Strengths, Weaknesses, Opportunities, Threats).

b. Membuat pemodelan dengan menggunakan BPMN untuk proses yang terkait.

c. Membuat matrik relasi fungsi bisnis dengan unit organisasi.

Tahap C: Perencanaan Arsitektur Sistem Informasi

Melakukan perencanaan arsitektur sistem informasi Monitoring Gizi Buruk pada Dinas Kesehatan Propinsi Jawa Barat yang meliputi perencanaan arsitektur data dan perencanaan arsitektur aplikasi. Langkah-langkah yang dilakukan adalah:

a. Melakukan perencanaan arsitektur data dengan menganalisis kelas-kelas data yang akan digunakan dalam sistem informasi Dinas Kesehatan Propinsi Jawa Barat, serta membuat relasi antara kelas-kelas data yang ada dengan menggunakan Class Diagram dan membuat tabel relasi fungsi bisnis dengan kelas data.

b. Membuat perencanaan arsitektur aplikasi yang meliputi: mengelompokan sistem informasi dan calon informasi yang dibutuhkan oleh Dinas Kesehatan Propinsi Jawa Barat yang menghasilkan daftar sistem informasi dan aplikasi, yang selanjutnya dibuatkan model proses pada sistem informasi monitoring gizi buruk dengan menggunakan Use Case Diagram, membuat matrik relasi fungsi bisnis dengan aplikasi.

Tahap D: Perencanaan Arsitektur Teknologi

Berisi tentang hasil perencanaan arsitektur teknologi informasi Dinas Kesehatan Propinsi Jawa Barat. Langkah-langkah yang dilakukan:

a. Membuat perencanaan infrastruktur dan jaringan dimasa yang akan datang.
Ova Nurisma Putra

Jurnal Ilmiah Teknologi Informasi Terapan

Volume III, No 2, 15 April 2017 
b. Merencanakan teknologi server dan data server yang akan digunakan guna untuk mendukung perencanaan arsitektur sistem aplikasi dan untuk menyimpan data keseluruhan.

c. Perencanaan Database: menetapkan spesifikasi teknologi database yang akan digunakan.

d. Perencanaan teknologi software yang akan digunakan.

e. Merencanakan kebutuhan komputer yang akan digunakan oleh Dinas Kesehatan Propinsi Jawa Barat.

f. Perencanaan pengelolan teknologi informasi yang digunakan

\section{Iterasi 3 : Transition Planning Iteration}

Iterasi Perencanaan Transisi, merupakan iterasi yang berupa peta jalan / road map bagi organisasi dalam penerapan arsitektur yang telah dibuat. Terdiri dari dua tahapan, yaitu:

Tahap E: Peluang dan Solusi

Tahapan ini fokus terhadap manfaat yang diraih dan solusi menentukan arsitektur Sistem Informasi yang akan diimplementasikan pada fase selanjutnya dalam TOGAF ADM.

\section{Tahap F: Perencanaan Migrasi}

Rencana migrasi dari sistem lama ke sistem baru yang sudah direncanakan berupa road map bagi organisasi dalam pengembangan aplikasi.

Dalam penelitian ini hanya sampai pada Tahap F: Perencanaan Migrasi. Tidak sampai pada Tahap G: Implementasi Pengelolaan Arsitektur dan Tahap H: Arsitektur Manajemen Perubahan pada Tahapan TOGAF ADM dalam merencanakan dan membangun framework proses pelayanan kesehatan di Dinas Kesehatan Propinsi Jawa Barat. Adapun alasannya yaitu:

1. Memerlukan waktu yang cukup lama dalam rekomendasi untuk pelaksanaan tata kelola yang sudah dilakukan berupa tabel rekomendasi tata kelola organisasi, tata kelola sistem informasi dan tata kelola arsitektur teknologi.

2. Belum ada kebijakan dalam menetapkan rencana manajemen arsitektur dari sistem yang baru dalam melakukan pengawasan terhadap perkembangan teknologi dan perubahan lingkungan orgnisasi, baik internal maupun eksternal untuk menentukan apakah akan dilakukan siklus pengembangan arsitektur enterprise berikutnya.

3. Belum ada kesiapan untuk pemantauan proses perubahan manajemen dalam memastikan bahwa EA merespon kebutuhan organisasi dan memaksimalkan nilai arsitektur untuk bisnis dalam mendukung sasaran perubahan arsitektur yang didefinisikan.

\section{PerencanaAn Arsitektur}

Berdasarkan metode penelitian pada bab sebelumnya, maka akan diusulkan perencanaan arsitektur dengan tahapan berikut:

\section{IV.1 Menentukan Visi}

Visi perencanaan aristektur adalah menghasilkan blueprint arsitektur sistem informasi rekam medis dan monitoring gizi buruk di Dinas Kesehatan Propinsi Jawa Barat. Dengan memberikan outcome dimana semua data informasi tentang rekam medis dan monitoring gizi buruk terintegrasi ke dalam satu data center melalui migrasi sistem lama ke sistem baru dalam waktu lebih kurang 5 tahun. Dalam waktu 5 tahun akan dilakukan tahapan migrasi dalam bentuk roadmap sistem informasi menuju tata kelola informasi ke dalam data terpusat untuk mempermudah mengakses semua informasi secara efektif dan efisien tentang hasil rekam medis dan monitoring terhadap gizi buruk tanpa memikirkan sarana infrastrukturnya dengan menggunakan model cloud computing dilingkungan Dinas Kesehatan Propinsi Jawa Barat dengan nama Medical Record and Monitoring (M2Rec).

\section{IV.2 Perencanaan Arsitektur Bisnis}

Pembuatan perencanaan arsitektur bisnis ini lebih jelas dan terperinci penjelasannya menggunakan rantai nilai (Value Chain) Porter (Harmon, 2007:3) dan pemodelannya menggunakan notasi BPMN (Business Proces Mapping Notation) (While A, 2005:5). Proses bisnis yang terjadi untuk rekam medis dan monitoring gizi buruk di Dinas Kesehatan Propinsi Jawa Barat dapat dikategorikan menjadi dua yaitu proses bisnis utama dan proses bisnis sebagai penunjang dari bisnis utama, hal tersebut dapat dilihat dalam Gambar 3.

\section{IV.2.1 Analisis SWOT}

Analisis SWOT digunakan sebagai dasar untuk merancang strategi dan program kerja dimana analisis ini membandingkan kondisi internal meliputi penilaian terhadap faktor kekuatan (Strength) dan kelemahan (Weakness) dan kondisi eksternal suatu organisasi mencakup faktor peluang (Opportunity) 
dan tantangan (Threats). Berdasarkan buku RENSTRA tahun 2010-2014 Dinas Kesehatan Propinsi Jawa Barat (Dinkes Jabar, 2010), maka analisis SWOT dapat dijelaskan sebagai berikut:

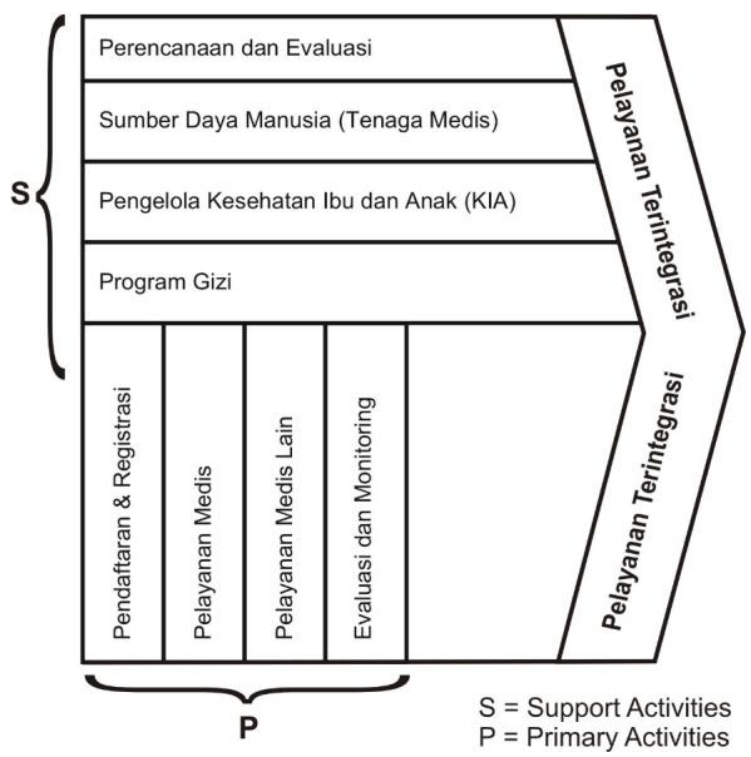

Gambar 3.

Value Chain Sistem Informasi Rekam Medis dan Monitoring Gizi pada Dinas Kesehatan Propinsi Jawa Barat

1) Kekuatan (Strength)

Merupakan keunggulan-keunggulan internal dan kondisi internal lainnya yang dimiliki oleh Dinas Kesehatan Propinsi Jawa Barat yang mendukung ke arah perkembangan pelayanan kesehatan yang baik. Kekuatannya adalah:

a. Dinas Kesehatan Propinsi Jawa Barat merupakan organisasi yang berbadan hukum.

b. Memiliki sistem pelayanan kesehatan yang baik.

c. Mempunyai Sumber Daya Manusia yang handal dalam pemahaman dari tujuan organisasi.

d. Fokus pada peningkatan kualitas pelayanan kesehatan

e. Memiliki tenaga ahli kesehatan/medis yang handal dan kompenten sesuai keilmuannya.

2) Kelemahan (Weakness)

Merupakan kelemahan-kelemahan internal dan kondisi internal lainnya yang dimiliki oleh Dinas
Kesehatan Propinsi Jawa Barat. Kelemahannya adalah:

a. Adanya fasilitas kesehatan yang belum terpenuhi di sebagian wilayah propinsi Jawa Barat.

b. Kurangnya proses pelayanan kesehatan secara berkesinambungan di daerah desa, kabupaten atau kota.

c. Masih adanya proses pelayanan kesehatan yang belum terkomputerisasi.

d. Masih kurang akuratnya data masyarakat dalam menggunakan fasilitas kesehatan.

e. Masih banyak data masyarakat dan tenaga medis yang belum terdata di bank data kesehatan propinsi Jawa Barat.

f. Kurangnya sosialisasi tentang program pelayanan kesehatan di masyarakat.

3) Peluang (Opportunity)

a. Kolaborasi adanya organisasi kesehatan melalui pengembangan jaringan pelayanan kesehatan.

b. Peningkatan pendanaan pelayanan kesehatan berbasis Teknologi Informasi (IT).

c. Masyarakat bermitra untuk mengembangkan program-program kesehatan yang baru.

d. Adanya pusat informasi klinis untuk penentu kebijakan kesehatan di tingkat lokal.

e. Adanya komitmen dan keterlibatan publik atas kepuasan pasien.

f. Adanya pelayanan Rumah Sakit dengan akses pasien lebih besar untuk kesehatan yang berkualitas. Sehingga meningkatkan reputasi organisasi di masyarakat.

4) Ancaman (Threats)

Merupakan faktor eksternal yang memungkinkan Dinas Kesehatan Propinsi Jawa Barat mengalami kegagalan dalam usahanya mencapai tujuan yang ditetapkan. Ancamannya adalah:

a. Adanya gangguan kebijakan dari politik atau ketidakstabilan ekonomi.

b. Meningkatnya permintaan oleh pasien dan dokter untuk teknologi kesehatan dengan harga yang mahal.

c. Adanya pertumbuhan penduduk yang tidak diasuransikan.

d. Meningkatkan tekanan untuk megurangi biaya kesehatan.

e. Meningkatkan defisit anggaran di Dinas Kesehatan. 


\section{IV.2.2 Pemodelan Arsitektur Bisnis}

Secara garis besar gambaran proses bisnis Dinas Kesehatan Propinsi Jawa Barat dapat dilihat pada Gambar 5.

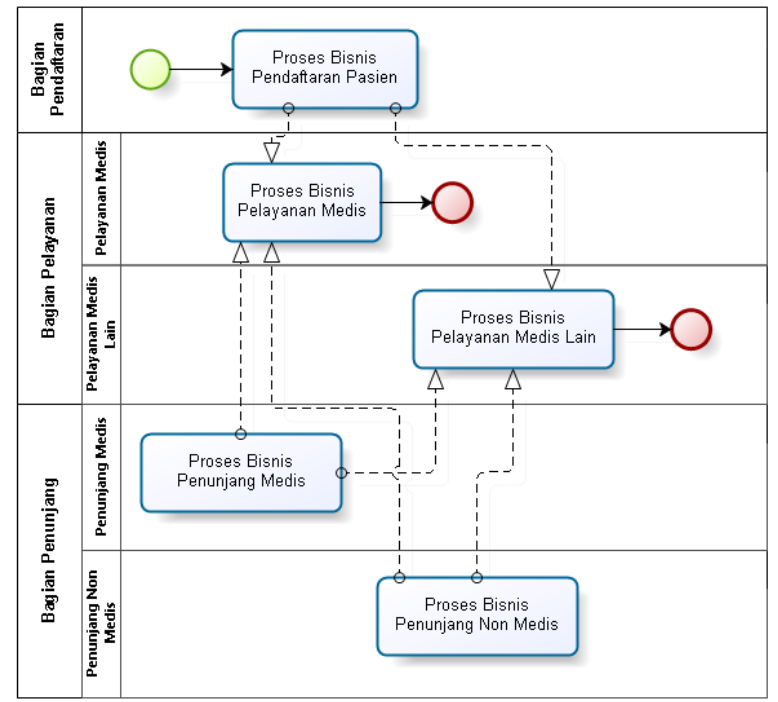

Gambar 5. Garis Besar Proses Bisnis

\section{IV.2.3 Perencanaan Arsitektur Sistem Informasi}

1) Perencanaan Arsitektur Data

Penetapan target perencanaan arsitektur data yaitu mendefinisikan kelas-kelas data yang digunakan pada perencanaan arsitektur aplikasi. Model yang digunakan dalam perencanaan arsitektur data menggunakan class diagram yang menggambarkan relasi antar data dan entitas yang ada dalam sistem informasi rekam medis dan monitoring gizi buruk. Yang dilakukan dalam perencanaan arsitektur data meliputi menganalisis kelas-kelas data dijelaskan pada tabel 1, membuat tabel relasi fungsi bisnis dengan kelas data dan memodelkan relasi kelas-kelas data dengan menggunakan Class Diagram yang dijelaskan pada Tabel 1.

Tabel 1. Kelas Data

\begin{tabular}{cl}
\hline \hline No Kelas & Kandidat Kelas \\
\hline \hline 1 & Pendaftaran \\
2 & Pelayanan Medis \\
3 & Pelayanan Medis Lain \\
4 & Rekam Medis \\
5 & Penunjang Medis \\
6 & Penunjang Non Medis \\
\hline \hline
\end{tabular}

Tahap selanjutnya adalah membuat pemodelan kelas data dengan menggunakan diagram class untuk menggambarkan relasi antar kelas yang telah di analisis dan dikelompokkan di atas. Adapun hasil dari diagram class secara garis besar dapat dilihat pada Gambar 6.

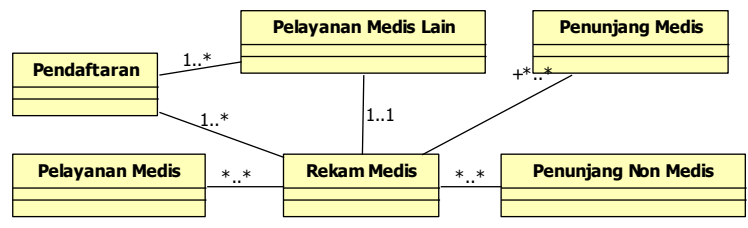

Gambar 6. Diagram Kelas Data

2) Perencanaan Arsitektur Aplikasi

Mengelompokkan arsitektur aplikasi yang dibutuhkan oleh Dinas Kesehatan Propinsi Jawa Barat, adapun arsitektur aplikasi secara garis besar dijelaskan pada Tabel 2.

Tabel 2. Aplikasi Sistem Informasi

\begin{tabular}{ccl}
\hline \hline No & No Aplikasi & Nama Aplikasi \\
\hline \hline 1 & APL1.1 & Aplikasi Pendaftaran \\
2 & APL1.2 & Aplikasi Pelayanan Medis \\
3 & APL1.3 & Aplikasi Pelayanan Medis Lain \\
4 & APL1.4 & Aplikasi Rekam Medis \\
5 & APL1.5 & Aplikasi Penunjang Medis \\
6 & APL1.6 & Aplikasi Penunjang Non Medis \\
\hline \hline
\end{tabular}

\section{IV.2.4 Perencanaan Arsitektur Teknologi}

Perencanaan arsitektur teknologi terdiri dari:

1) Infrastruktur dan Arsitektur Teknologi Jaringan

Untuk meningkatkan layanan dan komunikasi jaringan komputer yang lebih baik, cepat, akurat dan tidak ada error di antara setiap instalasi, bagian dan wilayah yang jauh dalam lingkungan sistem di Dinas Kesehatan Propinsi Jawa Barat untuk masa yang akan datang dapat dijelaskan pada Gambar 7.

Beberapa pengembangan yang dilakukan pada arsitektur teknologi jaringan adalah sebagai berikut:

1. Teknologi jaringan menggunakan model komputasi awan (Cloud Computing) pada pemanfaat platform application service (Mell \& Grance, 2011). Dengan menggunakan teknologi ini semua jenis pencatatan dan pelaporan masuk dan uptodate dari tiap tingkatan kebijakan akan bisa terakomodir secara cepat dengan pembiayaan hemat, ketersediaan tinggi dan 
skalabilitas mudah. Dapat diakses kapan dan dimana saja selama terdapat koneksi internet

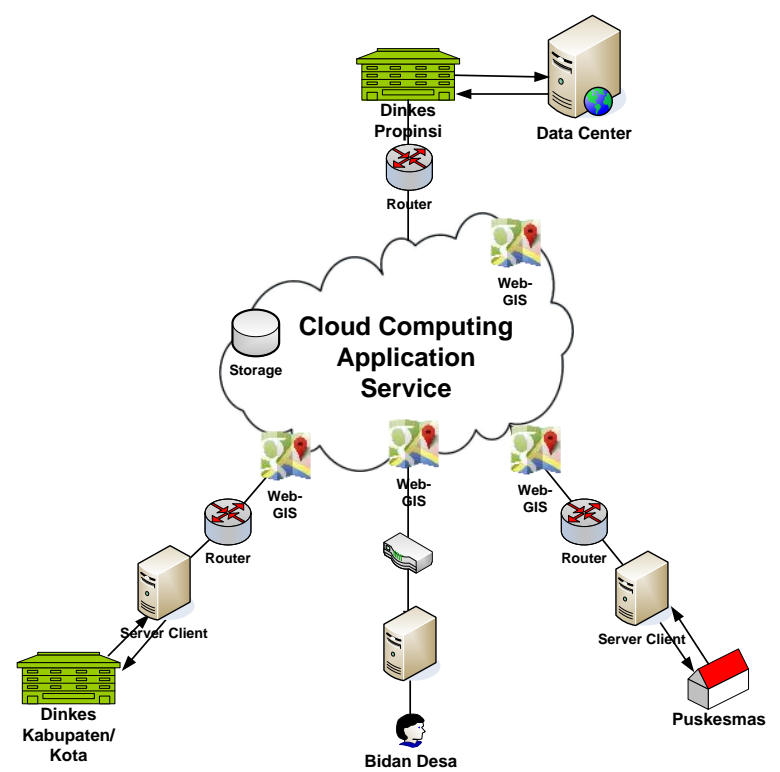

Gambar 7. Arsitektur Teknologi Jaringan

2. Layer Intranet (LAN) menggunakan Fiber Optic, yang menghubungkan setiap perangkat (komputer, printer, panel monitor) yang diakses untuk sistem aplikasi dan monitoring sistem dan lainnya.

3. Pada Cloud Computing -cloud services dan storage dapat diakses dari mana saja selama terdapat koneksi internet.

4. Cloud Computing menggunakan kombinasi teknologi processor baru berkecepatan tinggi, tenologi virtualiasi, distributed storage, broadband internet access, automated management serta server yang tidak terlalu mahal.

5. Cloud Computing lebih menekankan pada kepemilikan (proprietary), setiap pengguna cloud bisa mendapatkan sumber daya pribadi dari cloud, yang disediakan oleh service provider tertentu dan pengguna tidak perlu berkontribusi dalam penyediaan sumber daya.

6. Cloud Computing menekankan pada aplikasi transaksi, suatu permintaan dengan jumlah besar dan terpisah-pisah dan dapat untuk skala otomatis atau semi otomatis.

Untuk mengatur hak akses tiap tingkatan pencatatan dan pelaporan akan terintegrasi dalam satu layanan aplikasi monitoring gizi buruk dengan memanfaatkan teknologi jaringan dengan Cloud Computing. Adapun hak akses berdasarkan levelnya dapat dilihat pada Tabel 3.

Tabel 3. Hak Akses Sistem Informasi Rekam Medis dan Monitoring Gizi

\begin{tabular}{|c|c|c|c|}
\hline No & Level & Bagian & Hak Akses \\
\hline \multirow[t]{2}{*}{1} & Level 1 & Dinkes Propinsi & Dinkes Kabupaten, \\
\hline & & & $\begin{array}{l}\text { Puskesmas, Bidan } \\
\text { Desa }\end{array}$ \\
\hline 2 & Level 2 & $\begin{array}{l}\text { Dinkes Kabupaten/ } \\
\text { Kota }\end{array}$ & $\begin{array}{l}\text { Puskesmas, Bidan } \\
\text { Desa }\end{array}$ \\
\hline 3 & Level 3 & Puskesmas & Bidan Desa \\
\hline 4 & Level 4 & Bidan Desa & $\begin{array}{lr}\text { Hanya } & \text { bisa } \\
\text { mencatat dan } \\
\text { membuat laporan } \\
\text { data pelayanan pada } \\
\text { aplikasi }\end{array}$ \\
\hline
\end{tabular}

Adapun karakteristik arsitektur cloud computing yang dibangun adalah:

1. Broadband Network Access, layanan yang diberikan melalui jaringan internet, sehingga dapat di akses dimana saja dan kapan saja.

2. Resource Pooling, data yang dikases disediakan secara terpusat, sehingga pengguna tidak perlu tahu bagaimana dan darimana permintaan akan sumber daya komputasinya dipenuhi oleh provider, karena dapat digunakan secara masal/bersamaan. Dalam hal ini, di unit rumah sakit, puskesmas, bidan, dokter dan Dinkes Kabupaten/Kota yang diberikan fasilitas untuk langsung menggunakan aplikasi Medical Record and Monitoring (M2Rec). Karena setiap unit dibawah koordinasi Dinkes Propinsi Jawa Barat tidak perlu dibebankan dengan pembangunan aplikasi M2Rec. Jadi setiap unit di wilayah sebagai pengguna yang siap menggunakan aplikasi yang telah disediakan Dinkes Propinsi Jawa Barat sebagai penyedia fasilitas.

2) Spesifikasi Teknologi Server

Teknologi server yang digunakan dalam kegiatan operasional sehari-hari seharusnya terpisah dari aplikasi-aplikasi yang sedang dikembangkan dan harus memenuhi standar spesifikasi sebagaimana mestinya sebuah server, guna untuk menjamin keamanan server dan memudahkan pemeliharaan server. Teknologi server yang harus digunakan harus memadai untuk sebuah sistem informasi dan serverserver tersebut harus ditempatkan pada suatu tempat khusus yang memiliki rack cabinet server.
Ova Nurisma Putra

Jurnal Ilmiah Teknologi Informasi Terapan

Volume III, No 2, 15 April 2017 
3) Spesifikasi Database

Adapun spesifikasi database yang diusulkan adalah: MsSql Server 2008/Mysql/PosgresSql sebagai database server untuk aplikasi portal Dinas Kesehatan. MsSql Server sebagai database server untuk aplikasi SIMRS dan Apache/IIS sebagai web server.

4) Spesifikasi Software

Perangkat lunak untuk client menggunakan windows 7 atau linux sebagai sistem operasinya, sedangkan perangkat lunak aplikasi SIMRS menggunakan ArcGIS, Delphi Enterprise Edition, Fast Report dan Developer Express dan untuk portal Dinas Kesehatan Propinsi menggunakan PHP last version, Java / Vb Script, web 2 dengan teknologi ajak dan fusion chart.

5) Spesifikasi Hardware

Disesuaikan dengan kebutuhan Dinas Kesehatan Propinsi Jawa Barat.

\section{IV.2.5 Perencanaan Migrasi dan Implementasi}

Merupakan sebuah rekomendasi integrasi dan implementasi hasil dari perencanaan arsitektur sistem informasi antara sistem informasi yang sudah ada dengan sistem yang diusulkan dalam bentuk roadmap pengembangan sistem informasi. Roadmap tersebut dijelaskan pada Tabel 4.

Tabel 4. Roadmap Pengembangan Aplikasi

\begin{tabular}{|c|c|c|c|c|c|c|}
\hline \multirow{2}{*}{$\begin{array}{c}\text { No } \\
\text { Aplikasi }\end{array}$} & \multirow{2}{*}{ Nama Aplikasi } & \multicolumn{5}{|c|}{ TAHUN KE: } \\
\hline & & 1 & 2 & 3 & 4 & 5 \\
\hline APL1.1 & Aplikasi Pendaftaran & & & & & \\
\hline APL1.2 & Aplikasi Medis & & & & & \\
\hline APL1.3 & Aplikasi Medis Lain & & & & & \\
\hline APL1.4 & Aplikasi Rekam Medis & & & & & \\
\hline APL1.5 & Aplikasi Penunjang Medis & & & & & \\
\hline APL1.6 & Aplikasi Penunjang Non Medis & & & & & \\
\hline
\end{tabular}

Keterangan:

: Integrasi antara sistem lama dengan sistem baru

: Implementasi/pengembangan sistem baru

Kendala yang dihadapi dalam penelitian ini adalah pada pengumpulan data, tidak samanya format dokumen pencatatan dan pelaporan rekam medis dan tenaga medis, waktu pelaporan yang tidak serentak di setiap tingkat pelayanan kesehatan posyandu, polindes, balai pengobatan, puskesmas ditiap wilayah pemeriksaan di propinsi Jawa Barat. Untuk itu dapat diatasi dengan merencanakan arsitektur sistem informasi berbasis IT dengan nama mobile M2Rec (Medical Record and Monitoring). Dengan sistem ini masalah terhadap waktu pengiriman laporan dan pencatatan lebih cepat dan efektif dibandingkan sistem yang berjalan selama ini. Sehingga proses pemantauan atau monitoring hasil pelayanan kesehatan terutama pada perkembangan gizi bayi/balita akan lebih cepat informasinya sebagai bahan pertimbangan untuk pengambilan keputusan dalam manajemen di Dinas Kesehatan Propinsi Jawa Barat dengan pendekatan metode TOGAF ADM.

\section{KESIMPUlan DAN SARAN}

Permasalahan pencatatan dan pelaporan rekam medis dan monitoring gizi buruk selama ini sangat mempengaruhi kebijakan pengambilan keputusan yang dilakukan oleh Dinas Kesehatan Propinsi Jawa Barat dalam memetakan wilayah yang rawan akan gizi buruk. Ini disebabkan karena format data pencatatan dan pelaporan yang berbeda dan waktu pelaporan oleh tiap tingkat kebijakan tidak serentak dalam periodik pelaporan tiap bulannya dan ini dapat menghambat informasi secara uptodate untuk mendapatkan perkembangan status gizi balita di setiap daerah. Dengan merencanakan arsitektur sistem informasi rekam medis dan monitoring gizi buruk menggunakan framework TOGAF ADM dapat menghasilkan visi perencanaan arsitektur, perencanaan arsitektur bisnis, perencanaan arsitektur sistem informasi, perencanaan arsitektur teknologi, perencanaan peluang dan solusi, perencanaan migrasi dan implementasi berupa roadmap migrasi dan implementasi arsitektur teknologi berbasis Cloud Computing pada Dinas Kesehatan Propinsi Jawa Barat secara bertahap sesuai dengan jadwal dan target waktu yang telah tentukan.

Kesulitan dalam menerapkan TOGAF ADM terletak pada kelengkapan infrastruktur yang ada pada unit pelaksanaan pelayanan kesehatan sehingga harus diperbaiki dan dilengkapi. Solusi terbaik saat ini adalah dengan mengabaikan infrastruktur dengan menggunakan metode Cloud Computing untuk mengintegrasikan data informasi rekam medis dan monitoring gizi buruk secara terpusat sehingga dapat di akses dengan cepat dan tepat dalam mengambil keputusan oleh Dinas Kesehatan Propinsi Jawa Barat
Ova Nurisma Putra

Jurnal Ilmiah Teknologi Informasi Terapan Volume III, No 2, 15 April 2017 


\section{REFERENSI}

Ashari, A. dan Setiawan, H., 2011, Cloud Computing: Solusi ICT?, Jurnal Sistem Informasi (JSI), VOL. 3, NO. 2. Unsri.

http://www.ejournal.unsri.ac.id/index.php/jsi /article/download/736/277/736-1894-1-

PB.pdf

Dinkes Jabar, 2010, Buku Rencana Strategis (RENSTRA) 2010-2014

Handley, Jeff., 2008, Enterprise Architecture Best Practice Handbook.

Kemenkes RI, 2014, Peraturan Menteri Kesehatan Republik Indonesia nomor 25, Tentang Upaya Kesehatan Anak.

Kosidin, 2015, Perencanaan Arsitektur Sistem Informasi Rumah Sakit dengan Menggunakan The Open Group Architecture Framework (TOGAF) Architecture Development Method (ADM) (Studi Kasus Rumah Sakit Daerah dr. Slamet Kaupaten Garut), Prosiding Konferensi dan Temu Nasional Teknologi Informasi dan Komunikasi (TIK), ISSN: 978-979-18018-12.

Kurniawan, Bobi., 2010, Enterprise Architecture Plannig Sistem Informasi pada Perguruan Tinggi dengan Zachman Framework, Majalah Ilmiah UNIKOM Vol. 9 No. 1.

Kurniawan, E., 2015, Penerapan Teknologi Cloud Computing Di Universitas Studi Kasus: Fakultas Teknologi Informasi UKDW, Jurnal EKSIS Vol 08 No 01 Mei 2015: halaman 2936.

Mell, P., and Grance, T., 2011, The NIST Definition of Cloud Computing, National Institute of Standards and Technology (NIST).

http://csrc.nist.gov/publications/nistpubs/800 -145/SP800-145.pdf/ (diakses 19 Oktober 2011)

Pearlson, E., Keri, \& Saunder S., Carol., 2010, Managing and Using Information Systems A Strategic Approach. $4^{\text {th }}$ Ed, Wiley.

The Open Group. 2011. TOGAF Version 9.1. USA.
The Open Group and OMG, 2003, TOGAF ADM and MDA, The Power of Synergy, USA.

Ward, J., and Peppard, J., 2002, Strategic Planning for Information System, 3rd Ed, Wiley. 